\title{
TRAUMA HEALING SEBAGAI BENTUK PELAYANAN KONSELING PASTORAL PADA KASUS PERCABULAN
}

\author{
Christina Eryssa Widyaningrum \\ christinlovejesus55@gmail.com \\ Sekolah Tinggi Teologi Jemaat Kristus Indonesia
}

\begin{abstract}
Trauma healing as a form of pastoral counseling service, especially in cases of sexual harassment, is a sensitive but very necessary service. Victims often shut themselves off and do not open up because this is something that frightens them. Self-image recovery must take place by paying attention to various aspects, namely physical, social, mental and spiritual so that trauma recovery can occur completely.
\end{abstract}

Keywords: trauma healing, pastoral counseling, physical, social

\begin{abstract}
ABSTRAK
Trauma healing sebagai bentuk pelayanan konseling pastoral khususnya pada kasus pelecehan seksual atau percabulan merupakan pelayanan yang sensitif tetapi sangat diperlukan. Para korban seringkali menutup diri dan tidak terbuka karena hal tersebut merupakan hal yang menakutkan baginya. Pemulihan gambar diri harus terjadi dengan memperhatikan berbagai aspek yaitu fisik, sosial, mental dan rohani agar pemulihan trauma itu dapat terjadi secara utuh.
\end{abstract}

Kata kunci: trauma healing, konseling pastoral, fisik, sosial

\section{PENDAHULUAN}

Indonesia adalah negara yang terdiri dari berbagai pulau serta memiliki keragaman budaya dan bahasa. Setiap daerah memiliki satu bentuk budaya dimana ada nilai-nilai yang bisa dilakukan dan yang tidak boleh dilanggar atau tabu. Negara yang berlandaskan hukum seperti Indonesia memiliki landasan hukum yuridis dan adat. Hukum atau aturan itu dibuat karena ada pelanggaran. Orang yang melanggar hukum akan mendapat sanksi baik sanksi yuridis maupun sanksi adat.

Negara hukum seperti halnya Indonesia, kejahatan-kejahatan sosial masih marak terjadi. Beberapa kejahatan yang terjadi antara lain pembunuhan, pemerkosaan, pencurian, penindasan, pemaksaan. 
Kejahatan menurut R. Soesilo menjadi dua sudut pandang yaitu sudut pandang yuridis dan sosiologis.

Dalam sudut pandang yuridis menjelaskan bahwa kejahatan adalah suatu tingkah laku yang bertentangan dengan undang-undang, sedangkan sudut pandang sosiologis kejahatan adalah perbuatan atau tingkah laku yang selain merugikan penderita (korban) juga sangat merugikan masyarakat yaitu berupa hilangnya keseimbangan, ketentraman dan ketertiban. ${ }^{1}$

Jenis pelanggaran HAM dikategorikan berdasarkan bentuk pelanggaran HAM berat dan pelanggaran HAM ringan. Berdasarkan Undang-undang Nomor 26 tahun 2000 pada pasal 7 menjelaskan bahwa salah satu pelanggaran hak asasi manusia yang berat adalah kejahatan terhadap kemanusiaan. Dalam Undang-undang pasal 9 dijelaskan kembali:

Kejahatan terhadap kemanusiaan adalah salah satu perbuatan yang dilakukan sebagai bagian dari serangan yang meluas atau sistematik yang diketahuinya bahwa serangan tersebut ditujukan secara langsung terhadap penduduk sipil, salah satunya berupa bentuk-bentuk kekerasan seksual lainnya yang setara meliputi perkosaan, perbudakan seksual, pelacuran secara paksa, pemaksaan kehamilan, pemandulan atau sterilisasi secara paksa dan lainnya. ${ }^{2}$

Kitab Undang-Undang Hukum Pidana mengenal pelecehan seksual sebagai istilah percabulan. Percabulan adalah tindakan seseorang yang dilakukan secara sengaja dengan maksud seksual dan tidak seijin orang yang bersangkutan. R. Soesilo mengatakan percabulan atau perbuatan cabul adalah "segala perbuatan yang melanggar kesusilaan atau kesopanan atau perbuatan yang keji, semuanya itu dalam lingkup nafsu birahi kelamin misalnya: ciumciuman, meraba-raba anggota kemaluan, meraba-raba buah dada dsb." Percabulan secara lengkap dijelaskan dalam KUHP pasal 290 sebagai berikut:

Barang siapa melakukan perbuatan cabul dengan seseorang, padahal diketahuinya bahwa orang itu pingsan atau tidak berdaya. Barangsiapa melakukan perbuatan cabul dengan seseorang padahal diketahuinya atau sepatutnya harus diduganya, bahwa umurnya belum lima belas tahun atau kalau umurnya tidak jelas, yang bersangkutan belum waktunya untuk dikawin. Barangsiapa membujuk seseorang yang diketahuinya atau sepatutnya harus diduganya bahwa umurnya belum lima belas tahun

${ }^{1}$ Soesilo R, Kitab Undang-Undang Hukum Pidana (KUHP) Serta Komentar-Komentarnya (Bogor: Politeia,1985), 36.

2 Undang-Undang Republik Indonesia Nomor 26 Tahun 2000, Diakses pada Senin 31 Desember 2018.

3 Soesilo, Sistem Pidana di Dalam KUHP dan Pengaturannya menurut Konsep KUHP (Medan: USU Press, 2010),10. 
atau kalau umurnya tidak jelas yang bersangkutan belum waktunya untuk kawin, untuk melakukan atau membiarkan dilakukannya perbuatan cabul atau bersetubuh di luar perkawinan dengan orang lain. ${ }^{4}$

Komisi Nasional Anti Kekerasan terhadap Perempuan (Komnas Perempuan) meluncurkan catatan tahunan 2019. Dalam catatan tersebut Mariana Amiruddin (Komisioner Komnas Perempuan) menyebutkan bahwa

Di tahun 2019 ada kenaikan 14\% kasus kekerasan terhadap perempuan yaitu sejumlah 406.178 kasus. Data tersebut dihimpun dari tiga sumber yakni Pengadilan Negeri (PN) dan Pengadilan Agama (PA), lembaga layanan mitra komnas perempuan, dan Unit Pelayanan Rujukan (UPR). Mariana menjelaskan bahwa Catahu 2019 ditemukan fakta baru tentang kekerasan terhadap perempuan yakni perkosaan dalam pernikahan (marital rape), incest, kekerasan dalam pacaran (KDP), cybercrime, dan kekerasan seksual pada perempuan disabilitas. Sementara itu Adriana Venny (Komisioner Komnas Perempuan) menyampaikan bahwa dalam Catahu Komnas Perempuan memetakan jenis-jenis kekerasan seksual yang dilaporkan oleh korban yakni pelecehan seksual, eksploitasi seksual, pemaksaan penggunaan kontrasepsi, pemaksaan melakukan aborsi, perkosaan, pemaksaan perkawinan, pemaksaan pelacuran, perbudakan seksual, dan penyiksaan seksual. ${ }^{5}$

\section{METODE PENELITIAN}

Artikel ini ditulis dengan metode penelitian kualitatif deskriptif, yaitu melalui berbagai sumber literatur yang terkait tentang pelayanan konseling pastoral dan trauma healing. Sedangkan untuk persoalan yang diangkat, merupakan hasil dari studi kasus yang terjadi di dalam lingkungan sekitar peneliti. Dalam pembahasannya dimulai dengan mendefinisikan berbagai variabel yang terdapat dalam judul penelitian dan dilanjutkan dengan berbagai langkah pelayanan pastoral konseling yang dilakukan oleh berbagai lembaga dan mitra pelayanan penulis. Kekhususan artikel ini adalah spesifik pada persoalan pelecehan seksual atau percabulan yang cenderung tersamar dan tidak terungkap secara terbuka karena faktor etis.

\section{PEMBAHASAN}

\section{Pengertian Trauma}

Trauma menurut Kamus Besar Bahasa Indonesia Pusat Bahasa edisi ke empat adalah keadaan jiwa atau tingkah laku yang tidak normal sebagai

${ }^{4}$ Tim Redaksi BIP, peny. Saptono Raharjo, KUHP Kitab Undang-Undang Hukum Pidana dan KUHAP Kitab Undang-Undang Hukum Acara Pidana (Jakarta: Bhuana Ilmu Populer,2017), 119.

${ }^{5}$ Komisi Nasional Anti Kekerasan terhadap Perempuan, catatan tahunan tentang kekerasan terhadap perempuan 2019, diakses pada 20 Mei 2019 Pukul 07.14

https://www.jurnalperempuan.org/warta-feminis/catatan-tahunan-2019. 
akibat dari tekanan jiwa atau cedera jasmani. Menurut Webster Dictionary, "Trauma berasal dari bahasa Yunani trauma atau traumatos. Dalam bahasa psikiatri, kata ini berarti "suatu pengalaman emosional atau peristiwa yang mengejutkan dan peristiwa ini memiliki dampak yang berkelanjutan."6

Secara etimologis pengertian trauma adalah pengalaman yang menggoncangkan jiwa dan melibatkan pengalaman emosional serta berdampak pada kejiwaan seseorang. Memori itu akan tetap tersimpan di dalam otak manusia dan suatu saat jika hal tertentu terjadi, hal itu mengingatkan pada memori trauma maka akan ada reaksi baik secara fisik, psikis dan kejiwaan seseorang.

Pengalaman traumatis adalah "pengalaman yang mengakibatkan goncangan pada jiwa seseorang dan sangat memengaruhi emosi serta spiritualitas." 7 Orang yang memiliki pengalaman yang menggoncangkan jiwanya tentu akan memiliki pengaruh terhadap konsep dirinya. Seseorang akan memiliki tingkat emosi yang kadang tidak bisa dikontrol atau dikendalikan oleh dirinya sendiri.

\section{Jenis Pengalaman Traumatis}

Ada beberapa jenis pengalaman traumatis, diantaranya adalah: pengalaman traumatis yang disengaja, trauma karena peristiwa, dan trauma yang aktif pasif.

\section{Trauma yang Disengaja}

Trauma yang disengaja adalah pengalaman trauma yang dialami karena perbuatan itu "dilakukan atas dasar kesengajaan dan diinginkan seseorang." Contoh tindakan pelecehan atau pemerkosaan. Perbuatan ini dilakukan dengan motif yang tidak dapat dipastikan, karena keadaan, karena keinginan yang tidak tersalurkan atau karena kelainan dan faktor lain dari si pelaku.

Tindakan tersebut dilakukan secara sepihak dan tanpa persetujuan korban. Adapun trauma yang tidak disengaja misalnya kecelakaan mobil. Trauma yang tidak disengaja tidak dapat ditafsirkan kapan, dimana, bagaimana, mengapa, apa dan siapa yang akan mengalami. Trauma kecelakaan misalnya, bisa dialami oleh siapa saja.Trauma ini tidak diinginkan korban, atau bahkan tidak ada unsur campur tangan pelaku yang mengakibatkan terjadinya kecelakaan.

\section{Trauma Karena Peristiwa}

Trauma karena satu peristiwa (misalnya musibah/bencana). Musibah dan bencana dapat mengakibatkan trauma. "Dampak yang ditimbulkan seperti

6 Noah Webster, Webster's New Universal Unabridged Dictionary (New York: World Publishing Co, 1979), 1942.

7 Thomas J. Sappington, Ibid 60.

8 Thomas J. Sappington, Ibid 61. 
dampak pada fisik, pikiran, perasaan, dan perilaku yang membekas bagi mereka yang mengalami atau hanya sekedar menyaksikan." Bencana alam mengakibatkan banyak hal yang memicu terjadinya trauma. Secara fisik, bagi seseorang yang ikut mengalami suatu bencana akan ada trauma karena kontak dengan benda-benda di sekelilingnya dan mengakibatkan sakit pada fisiknya. Pikiran mereka akan merekam memori yang membuat mereka merasakan trauma. Dan adapun yang merupakan suatu keadaan yang terus berlangsung (misalnya penolakan dalam konteks keluarga). "Penolakan yang terjadi dalam konteks keluarga dapat terjadi karena beberapa faktor antara lain: kelahiran yang tidak diinginkan, masa lalu yang pahit dan faktor lainnya." ${ }^{" 10}$

\section{Trauma Aktif}

Trauma juga dapat bersifat aktif yaitu, menurut Kamus Besar Bahasa Indonesia adalah "giat, dinamis atau bertenaga sebagai lawan dari statis." 11 Pengalaman trauma biasanya terjadi pada suatu waktu tertentu dan menimbulkan dampak yang berkelanjutan. Bagian ini trauma dapat bersifat aktif karena dilakukan berulang kali secara aktif. Adapun pengalaman trauma yang aktif seperti penganiayaan fisik, emosi atau seksual. Pengalaman trauma aktif terjadi berkelanjutan. Pihak korban mengalami pengalaman yang mengakibatkan trauma setiap kali penganiayaan itu dilakukan.

Beberapa istilah Kamus Webster untuk mendefinisikan kata "abuse" ialah (kata kerja) "menyalahgunakan"; "menggunakan secara keliru"; "menyakiti dengan memperlakukan secara kejam"; "menganiaya"; "menggunakan bahasa yang menghina, kasar atau buruk"; "mencacimaki"; (kata benda) "pemanfaatan yang keliru, buruk atau berlebihan"; "penganiayaan"; "luka-luka"; "kebiasaan atau perbuatan buruk, tidak adil, atau jahat";"'bahasa yang menghina atau kasar."12

Sesuai dengan keterangan di atas mengenai abuse jelas dikatakan pihak pelaku menyalahgunakan, menyakiti dan memperlakukan secara kejam. Hal-hal ini yang mengakibatkan terjadinya trauma aktif secara fisik, emosi dan seksual.

\section{Trauma Pasif}

Trauma yang pasif misalnya seorang anak tidak menerima kasih dan perhatian dari orangtuanya. Seseorang seharusnya mendapatkan kasih

${ }^{9}$ Irma S. Martam, Mengenali Trauma Pasca Bencana, Pulih, 14 Desember 2009, 2. http://www.pulih.or.id/res/publikasi/news_letter_14.pdf

${ }^{10}$ Thomas J. Sappington, Ibid61.

${ }^{11}$ Kamus Besar Bahasa Indonesia Pusat Bahasa Edisi keempat, ibid31.

12 Houghton Mifflin Webster's II New Riverside University Dictionary (Boston Company, Massachusetts 1984). 
sayang dari keluarga. Semua anggota keluarga seharusnya berfungsi secara sehat, seorang Ayah menjalankan tugas dan tanggungjawabnya sebagai seorang ayah, seorang lbu seharusnya menjalankan tugas dan tanggungjawabnya sebagai seorang ibu dan begitupun anak menjalankan tugas dan tanggungjawabnya sebagai seorang anak.

Anggota keluarga jika tidak berfungsi optimal, misalnya anak tidak memperoleh kasih sayang dari orangtuanya akan mengakibatkan trauma yang pasif. Anak merasa sangat dirugikan karena kehilangan kasih sayang yang seharusnya mereka dapatkan, sedangkan orangtua kehilangan relasi dengan anak-anak mereka karena mengabaikan tanggungjawabnya.

\section{Faktor-Faktor Traumatis yang Memengaruhi Manusia Secara Negatif}

Ada berbagai faktor traumatis yang spesifik yang dapat mempengaruhi kita secara negatif. Berbagai faktor traumatis ini dapat mengakibatkan berbagai hal yang buruk pada seseorang.

\section{Penolakan}

Penolakan adalah aksi karena tidak diinginkan kehadirannya. Seseorang itu ada dan hadir tetapi tidak diharapkan sehingga timbullah penolakan. Definisi penolakan adalah "suatu trauma yang dialami oleh manusia jika kita tidak diterima dan dikasihi oleh orang-orang lain yang seharusnya menerima dan mengasihi kita. ${ }^{13}$

Penolakan bisa terjadi kapanpun. Penolakan pada waktu masih dalam kandungan, ketika lahir bahkan ketika sudah bertumbuh dan menjadi dewasa. Ada dua macam penolakan, pertama kurangnya kasih sayang: kita tidak diperhatikan dan disayangi oleh orang-orang lain, khususnya orangtua kita. Penolakan yang dialami seorang anak dari orangtuanya disebut sebagai penolakan pasif. Kedua: penganiayaan atau kekejaman, kita diperlakukan dengan cara-cara yang sungguh menyakiti. Penolakan yang sengaja dilakukan untuk merugikan pihak korban disebut sebagai penolakan yang aktif.

Tak seorangpun dapat hidup luput sama sekali dari penolakan.

Semua orang mengalami beberapa penolakan. Apabila cukup banyak penolakan yang meninggalkan bekas-bekas luka, orang tersebut bukan saja dapat berfungsi abnormal dalam hubungannya dengan dengan orang lain, melainkan juga dalam hubungannya dengan Tuhan. ${ }^{14}$

\footnotetext{
${ }^{13} /$ bid, 61.

${ }^{14}$ Joyce Meyer, Perhiasan Kepala Ganti Abu Bebas Dari Kenangan Menyakitkan (Jakarta: Metanoia, 1994), 79.
} 
Semua orang pada kenyataannya pasti mengalami beberapa penolakan dalam hidup mereka. Ada yang mengalami penolakan dalam lingkungan keluarga, masyarakat dan komunitas tertentu.

Penolakan yang terjadi mengakibatkan hal-hal yang buruk khususnya bagi korban penolakan. Seseorang yang tidak diterima dalam lingkungan keluarga akan mengakibatkan trauma yang mendalam, konsep dirinya akan berubah. la akan cenderung menyalahkan dirinya sendiri dan menyesali karena faktor yang tidak ia ketahui atau bahkan ia ketahui mengapa ia ditolak dari lingkungan keluarganya sendiri.

\section{Pelecehan}

Pelecehan sangatlah luas, ada beberapa jenis pelecehan. Tindakan pelecehan adalah tindakan yang dilakukan secara sepihak dan merugikan korban. Ada dampak pelecehan yang langsung bisa dirasakan oleh korban tetapi ada juga akibat pelecehan yang tidak dirasakan korban secara langsung.

Pelecehan adalah tindakan seseorang menyentuh bagian-bagian tubuh tertentu khususnya payudara, alat kelamin, paha atau pantatatau mencium orang lain dengan maksud yang seksual dalam situasi yang tidak pantas. Paling sering laki-laki melakukannya kepada perempuan, remaja, atau seorang wanita muda. ${ }^{15}$

Pelecehan tersebut berhubungan dengan fisik. Pelecehan jenis ini yang langsung bisa dirasakan oleh korban karena berhubungan langsung dengan fisik korban. Hal ini juga sama akan langsung dirasakan dampaknya dari tindakan pelecehan yang dilakukan. Dampak traumatis akan lebih besar dialami oleh orang-orang yang dilecehkan secara fisik.

Pelecehan juga dapat dilakukan secara verbal. "Pelecehan jenis ini mungkin yang banyak dialami oleh perempuan, juga menjadi tindak pelecehan yang sulit ditindaklanjuti karena ketidakcukupan bukti."16 Pelecehan jenis verbal memang sulit untuk ditindaklanjuti karena bukti yang kurang kuat. Jika dibiarkan tindakan yang dilakukan secara verbal dapat mengakibatkan pelecehan yang lebih lanjut dan lebih serius.

Pelaku kejahatan pelecehan seksual juga terkadang menggunakan tindakan pelecehan secara gerak tubuh atau (Gesture). "Secara umum tindakantindakan ini juga merendahkan wanita seperti pandangan yang menatap penuh dengan nafsu dari rambut sampai ke kaki; lirikan mata yang menunjukkan hasrat seksual dan berdecak lidah sambil melihat bagian-

15 Ibid, 61.

${ }^{16}$ Muthia Esfand, Women Self Defense(Jakarta: Visi Media, 2012), 89. 
bagian tubuh." ${ }^{17}$ Korban pelecehan memang tidak merasakan dampaknya secara langsung seperti jika pelecehan dilakukan secara fisik. Tindakan pelecehan jenis gesture ini juga menimbulkan rasa yang tidak nyaman dan tidak aman. Kelihatannya pelecehan jenis gesture juga sering dilakukan oleh beberapa orang bahkan di manapun. Hanya korban terkadang tidak mengerti dan tidak mengalami dampaknya secara langsung kalau mereka sedang dilecehkan.

\section{Pengalaman yang Dramatis}

Pengalaman yang dimaksudkan adalah pengalaman yang menakutkan. "Beberapa pengalaman yang menakutkan diantaranya adalah kecelakaan, kerusuhan, kekerasan dan segala macam pengalaman yang menakutkan." ${ }^{18}$ Beberapa pengalaman ini mengakibatkan ketakutan. Seseorang akan merasa ketakutan dan trauma jika berada pada tempat, suasana dan kondisi tertentu yang mengingatkan mereka pada pengalaman-pengalaman yang menakutkan bagi mereka.

Kecelakaan menjadikan beberapa orang takut mengendarai kendaraan bermotor maupun mobil, tetapi oleh beberapa orang hal ini dapat dianggap sebagai hal yang biasa. Kerusuhan sebagian besar orang akan takut dengan kejadian itu. Apalagi kekerasan baik fisik maupun verbal mayoritas orang baik anak-anak maupun dewasa akan merasa takut dan trauma jika terulang kembali.

Dampak yang ditimbulkan dari pengalaman dramatis bisa jadi mimpi-mimpi yang buruk. Bahkan bisa meluas menjadi ia kurang berani dan kurang beriman.

\section{Disfungsi Gender}

Keluarga yang sehat akan berdampak baik pada pertumbuhan dan perkembangan anggota-anggotanya. Mereka dapat bertumbuh secara fisik dan psikis dengan seimbang karena, lingkungan terdekat mereka mendukung pertumbuhan itu. Disfungsi gender adalah "perilaku yang tidak dewasa yang dilakukan oleh salah satu anggota keluarga yang merusak pertumbuhan individu, ketrampilan untuk membangun hubungan yang sehat dalam keluarga." ${ }^{19}$ Anggota keluarga dilemahkan secara emosional, psikologis dan rohani.

Disfungsi gender yang terjadi dalam keluarga jelas melemahkan secara emosi, psikologis dan rohani individu. Disfungsi gender ini kemudian menjadi keluarga disfungsional. Dalam kehidupan seorang pria dampak disfungsi ayahnya akan berakibat buruk pada sang anak. Pengalaman penganiayaan

${ }^{17}$ Ibid., 90.

${ }^{18}$ Thomas J. Sappington., Ibid63.

19 June Hunt, Pastoral Konseling Alkitabiah Menjawab Isu-Isu Etika Sekuler Masa Kini 2 (Yogyakarta: ANDI,2015) 356. 
ayah kepada anak prianya akan menimbulkan reaksi menghakimi semua pria dan memisahkan diri dari mereka.

Reaksi lain yang akan timbul adalah menganggap dirinya layak untuk dianiaya, diperlakukan dengan tidak baik, diejek, diabaikan dengan akibat ia menghina dirinya sendiri atau menolak jenis kelaminnya. Akibat yang ditimbulkan dari perilaku ini adalah sang anak yang menjadi korban disfungsi akan kekurangan kasih sayang dan penguatan dari sesama jenis."Jelas karena ia tidak memperoleh kasih sayang dari anggota keluarga yang sesama jenis maka, ia akan merindukan dan mencari kasih sayang dari orang yang sesama jenis." ${ }^{20}$ Kapasitasnya untuk dapat mengembangkan karakteristik-karakteristik dari anggota keluarga yang sesama jenis akan terhambat.

\section{Pengertian Percabulan Menurut Alkitab}

Alkitab dengan jelas menuliskan dan tidak menutupi kejahatan-kejahatan yang dilakukan manusia. Beberapa peristiwa yang dituliskan secara eksplisit adalah kejahatan terhadap perempuan. Kejahatan terhadap perempuan sudah terjadi sejak masa Perjanjian Lama. Dalam Perjanjian Baru juga mengenal istilah kejahatan terhadap perempuan dengan istilah yang berbeda.

\section{Percabulan Dalam Perjanjian Lama}

Perjanjian Lama mengenal beberapa istilah yang tergolong pada kejahatan terhadap perempuan. Beberapa istilah kejahatan terhadap perempuan diantaranya adalah Kejadian 34:2 "Ketika itu terlihatlah ia oleh Sikhem, anak Hemor, orang Hewi, raja negeri itu, lalu Dina itu dilarikannya dan diperkosanya." Genesis 34:2 And when Shechem the son of Hamor the Hivite, the prince of the land, saw her, he took her and lay with her by force. Memperkosa menggunakan kata laywith her by force dalam bahasa Ibrani (wion ${ }^{\circ}{ }^{1} \mathrm{kab}$ ) lay down yang artinya berbaring.

2 Samuel 13:14 "Tetapi Amnon tidak mau mendengarkan perkataannya, dan sebab ia lebih kuat dari padanya, diperkosanyalah dia, lalu tidur dengan dia." 2 Samuel 13:14 However, he would not listen to her; since he was stronger than she, he violated her and lay with her. Diperkosa menggunakan kata

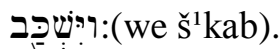

Sebelum perbuatannya, "Amon bin Daud jatuh cinta kepadanya (Tamar). Hati Amon sangat tergoda, sehingga ia jatuh sakit karena Tamar, saudaranya itu, sebab anak perempuan itu masih perawan dan menurut anggapan Amnon mustahil untuk melakukan sesuatu terhadap dia." (2 Samuel 13:1-2).

${ }^{20}$ Thomas J. Sappington, Ibid62. 
Tamar bukanlah seorang sundal, tapi fantasi seks di kepala Amnon telah mengacaukannya sampai-sampai membuatnya sakit. Dia sudah terbiasa untuk memandang dalam nafsunya. Jalan pelepasan bagi dia sudah sirna. Mungkin dia sudah bersetubuh dengan Tamar berkali-kali dalam imajinasinya. Nafsu yang demikian akan menuntut sesuatu yang nyata. Akhirnya Amnon dan temannya, Yonadab menyusun skenario agar Tamar datang ke dalam kamar Amnon. ${ }^{21}$

Kasus percabulan yang terjadi pada zaman Perjanjian Lama antara Amnon dan Tamar, terjadi kontak fisik. Keinginan itu muncul dalam hati Amnon dan kemudian keinginan itu dibuahi dengan tindakan. "Tamar menaburkan abu di atas kepalanya dan mengoyakkan busana keputriannya yang menandakan keperawanannya. ${ }^{22}$

Perjanjian Lama mengenal istilah percabulan berdasarkan ayat-ayat di atas

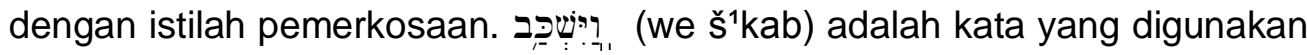
untuk menjelaskan istilah percabulan yang termasuk di dalamnya adalah tindakan pemerkosaan. Dalam hal ini tindakan pemerkosaan adalah tindakan yang dilakukan secara langsung, sepihak dan merugikan korban.

\section{Percabulan Dalam Perjanjian Baru}

Paulus menuliskan surat kepada beberapa jemaat yang tertulis dalam Perjanjian Baru. Kota Korintus salah satunya, kota yang banyak dengan persoalan. Persoalan yang dihadapi adalah kondisi kehidupan seksualitas di antara anggota jemaat. ${ }^{23}$ Kata cabul dan percabulan banyak digunakan dalam beberapa surat di dalam Alkitab.

\section{Dosa Seksual}

Markus 7:21 sebab dari dalam, dari hati orang, timbul segala pikiran jahat, percabulan, pencurian, pembunuhan, For from within, out of men's hearts, come evil thoughts, sexual immorality, theft, murder, adultery.

Kata percabulan menggunakan kata asli pornei/ai berasal dari kata pornei/a yang artinya perzinahan. Terjemahan lain dari sexual imorality, unchastity, prostitution, fornication, of various kinds of lawful sexual intercourse yang artinya, ketidaksenonohan, prostitusi, percabulan, berbagai jenis hubungan seks yang melanggar hukum.

${ }^{21}$ Neil. T Anderson, Jalan Pelepasan Kebebasan dari Belenggu Seksual (Ungaran: Kanugrahan, 2004), 105.

${ }^{22}$ Nico Ter Linden, Cerita Itu Berlanjut Cara Baru Membaca Hakim-Hakim dan Raja-Raja (Jakarta : BPK Gunung Mulia, 2009), 179.

${ }^{23}$ Samuel Benyamin Hakh, Perjanjian Baru Sejarah, Pengantar dan Pokok-pokok Teologisnya (Bandung: Bina Media Informasi, 2010), 139. 
2 Korintus 12:21 Aku kuatir, bahwa apabila aku datang lagi, Allahku akan merendahkan aku di depan kamu, dan bahwa aku akan berdukacita terhadap banyak orang yang di masa yang lampau berbuat dosa dan belum lagi bertobat dari kecemaran, percabulan dan ketidaksopanan yang mereka lakukan.

I am afraid that when I come again my God will humble me before you, and I will be grieved over many who have sinned earlier and have not repented of the impurity, sexual sin and debauchery in which they have indulged.

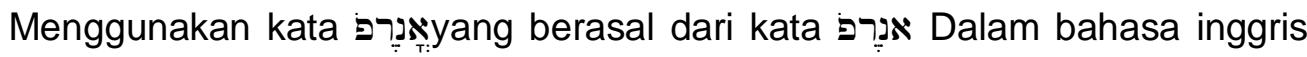
menggunakan kata sexual sin atau dosa seksual.

Matius 15:19 sebab dari hati timbul pikiran-pikiran jahat, yang menyebabkan orang membunuh, berzinah, berbuat cabul, mencuri, memberi kesaksian palsu dan memfitnah.For out of the heart come evil thoughts, murder, adultery, sexual immorality, theft, false testimony, slander.

\section{Perzinahan}

Kata percabulan menggunakan kata pornei/ai yang berasal dari kata pornei,a artinya perzinahan. Kata ini muncul $25 x$ di dalam Perjanjian Baru. Merupakan kata benda yang menunjukkan objek bergender feminim.

Perzinahan dalam bahasa Inggris menggunakan kata sexual immorality yang artinya amoralitas seksual. Amoralitas berasal dari kata amoral yang artinya tindakan yang tidak bermoral dan tidak berakhlak. Sedangkan dalam bahasa Indonesia adalah perbuatan bersenggama antara laki-laki dan perempuan yang tidak terikat oleh hubungan pernikahan.

Ayat di atas menjelaskan kata yang digunakan adalah kata pornei,a yang artinya perzinahan. Dalam konteks ayat tersebut percabulan, yang artinya berzinah adalah perbuatan-perbuatan yang dilakukan secara nyata atau secara fisik. Sedangkan dalam Matius 5:28 "Tetapi Aku berkata kepadamu: setiap orang yang memandang perempuan serta menginginkannya, sudah berzinah dengan dia di dalam hatinya."

Ayat Mat. 5:28 menekankan lebih jelas lagi, perzinahan yang dimaksudkan menginginkan seseorang di dalam hati sudah merupakan perzinahan. Perbuatan yang diinginkan dan ada di dalam hati sudah dianggap melakukan.

Alkitab melarang imoralitas seksual karena dua alasan yang terkait.

Pertama, Ketidaksetiaan atau dosa seksual melanggar rencana

Allah bagi kekudusan perkawinan manusia. Terlibat dalam hubungan seksual yang bukan pasangan, entah secara fisik atau mental melalui nafsu dan fantasi, merusak pola Allah. ${ }^{24}$

${ }^{24}$ Neil. T Anderson., Ibid68. 
Perjanjian Baru menggunakan beberapa istilah untuk kata percabulan diantaranya adalah dosa seksual dan perzinahan. Kedua istilah yang digunakan dalam Perjanjian Baru merupakan tindakan amoralitas seksual yaitu perbuatan yang tidak bermoral dan berakhlak. Tindakan tersebut dilakukan oleh pasangan yang tidak terikat oleh hubungan perkawinan. Dalam Perjanjian Baru percabulan didefinisikan lebih detail lagi pada Matius 5:28 Tetapi Aku berkata kepadamu: setiap orang yang memandang perempuan serta menginginkannya, sudah berzinah dengan dia di dalam hatinya. Perjanjian baru menyatakan setiap orang yang mengingini perempuan dalam hatinya sudah merupakan perbuatan perzinahan.

\section{Korban Percabulan}

Korban tindakan kejahatan terhadap perempuan dalam hal ini yang merujuk pada ranah percabulan adalah: orang-orang yang dirugikan secara langsung akibat tindakan kejahatan yang dilakukan pelaku. Menurut Undang-Undang Nomor 13 Tahun 2006 tentang Perlindungan Saksi dan Korban menyebutkan "korban adalah orang yang mengalami penderitaan fisik, mental, dan/atau kerugian ekonomi yang diakibatkan oleh suatu tindak pidana." ${ }^{25}$

\section{Perdagangan Manusia}

Tindakan penjualan manusia secara sengaja dapat terjadi dimana saja. Tindakan human trafficking bermacam-macam di lingkungan masyarakat perkotaan maupun pedesaan.Tindakan ini dilakukan dengan motif mencari keuntungan bagi pelaku-pelaku human trafficking. Eksploitasi yang dilakukan salah satunya digunakan untuk pemaksaan pekerjaan. Faith Alliance Against Slavery and Trafficking (FAAST) yaitu Lembaga Internasional yang bergerak dalam bidang penanganan Perdagangan Manusia menjelaskan demikian:

Perdagangan Manusia adalah perekrutan, pengangkutan, pemindahan, penampungan atau penerimaan seseorang, melalui ancaman atau unjuk kekuatan atau bentuk lain dari pemaksaan, penculikan, pemalsuan, penipuan, penyalahgunaan kekuasaan atau kerentanan posisi atau memberi atau menerima pembayaran atau keuntungan untuk mendapatkan persetujuan seseorang yang memegang kendali atas orang lain, dengan tujuan eksploitasi. ${ }^{26}$

Hal ini akan menimbulkan tindakan pemaksaan prostitusi. Tindakan ini merupakan tindakan percabulan karena, dilakukan secara sepihak dan untuk kepentingan pribadi yang merugikan orang lain.

${ }^{25}$ Undang-Undang Nomor 23 Tahun 2004.

${ }^{26}$ Faith Alliance Against Slavery and Trafficking,37. 


\section{Korban Bullying}

Bullying adalah suatu tindakan yang sering kali terdengar di lingkungan anak sekolah. Hal ini semacam menjadi budaya bagi anak-anak dan biasa dilakukan di lingkungan mereka. "Bullying adalah bentuk intimidasi atau penindasan dari satu individu atau kelompok yang lebih kuat. ${ }^{27}$

Tindakan Bullying dapat dilakukan kepada anak yang lebih lemah dan memiliki "kelemahan" tertentu sehingga menjadi bahan bullying bagi teman-teman sebayanya. Tindakan ini merupakan aksi serius yang berakibat fatal pada mental seorang anak dan menjadi penyakit jangka panjang. Seseorang yang dibully akan merasa dirinya tidak berharga, tidak pantas dan berbeda dengan temanteman sebayanya. Dampak tekanan emosi pada bullying dapat memicu stres, orang yang mengalami stres dapat timbul patofisiologis stres.

Akibatnya orang-orang yang menjadi korban bullying akan mencari komunitas yang dapat menerima dirinya, atau bahkan melampiaskan emosi yang dialami dengan berbagai tindakan. Tindakan-tindakan ini dapat merupakan tindakan yang keliru dan merugikan dirinya sendiri.

\section{Dampak Tindakan Percabulan}

Korban tentu akan mengalami trauma dan mempengaruhi banyak aspek dalam kehidupannya. Beberapa aspek kehidupan korban yang akan dipengaruhi oleh tindakan percabulan antara lain terhadap konsep diri sendiri, relasi dalam keluarga, keadaan emosi, dan keadaan spiritual.

\section{Terhadap konsep diri}

Trauma akibat tindakan percabulan berakibat fatal pada konsep diri seseorang. Gambar diri yang menurutnya semula baik akan berubah menjadi rusak. Trauma akibat tindakan ini mengakibatkan seseorang merasa jijik dengan dirinya sendiri. Hal ini merupakan perubahan konsep diri seseorang akibat trauma.

Konsep dan gambar diri manusia memang dibagi menjadi tiga bagian. Pertama sebelum jatuh dalam dosa; kedua setelah jatuh dalam dosa dan ketiga setelah hidup baru. Sebelum manusia jatuh ke dalam dosa segala sesuatu berjalan baik adanya, mereka menjalin komunikasi yang sangat baik bersama dengan Tuhan.

Manusia tidak melakukan kejahatan dan hidup damai bersama Tuhan. Alkitab menyatakan beberapa hal yang berkaitan dengan hubungan manusia dengan Allah sebelum mereka jatuh kedalam dosa. Dalam Kejadian 2:8-25 dijelaskan

27 https://hellosehat.com/hidup-sehat/psikologi/dampak-bullying-pada kesehatan-mentaldan-fisik-anak/ Rabu, 16 Januari 2019 Pukul 04.39 
keadaan manusia dan taman Eden yang indah. Hubungan manusia dengan Allah berjalan dengan baik dan memiliki keintiman. Mereka dapat bercakapcakap dengan leluasa serta berhubungan dekat dengan Allah.

Kejadian 2:7 mengemukakan bahwa manusia yang diciptakan Allah itu terbentuk dari debu tanah dan padanya dihembuskan napas kehidupan (Ibr. Nefes hayyah). Dengan demikian, manusia sebagai individu (pribadi) memiliki dimensi fisik (jasmani) yang terikat kepada alam. Di samping itu, manusia memiliki aspek non fisik atau rohani (spiritual). Adanya nefes hayyah itu membuat manusia membutuhkan Allah dalam seluruh kehidupannya. ${ }^{28}$

Pendapat Junihot berdasarkan Kejadian 2:7 menunjukkan keadaan manusia dan dimensi yang dimiliki manusia. Nefes hayyah menunjukkan kebergantungan penuh manusia kepada Allah dalam hidupnya.Oleh karena kebergantungan penuh manusia kepada Tuhan, jika terjadi masalah maka akan berpengaruh terhadap banyak aspek hidup manusia. Hal ini dapat dilihat melalui keadaan manusia setelah jatuh ke dalam dosa.

Manusia yang telah jatuh kedalam dosa menjadikan segala sesuatu berubah total. Hubungannya dengan Tuhan Allah menjadi terputus dan hidup terpisah dengan Tuhan Allah. Manusia bekerja keras sepanjang hidupnya dan harus mengupayakan untuk dapat bertahan hidup."Dengan berpeluh engkau akan mencari makananmu, sampai engkau kembali lagi menjadi tanah, karena dari situlah engkau diambil; sebab engkau debu dan engkau akan kembali menjadi debu" (Kej. 3:19). Ayat Firman Tuhan yang dituliskan dalam Kejadian 3:19 sebagai dampak kejatuhan manusia ke dalam dosa serta konsekuensi dari Allah yang harus ditanggung.

Konsep manusia setelah hidup baru berbeda pada waktu manusia jatuh ke dalam dosa. Hidup baru yang dimaksudkan adalah manusia setelah hidup di dalam Kristus oleh karena percaya dan ditebus dengan pengorbanan Tuhan Yesus di kayu salib. "Karena la telah membuka jalan yang baru dan yang hidup bagi kita melalui tabir, yaitu diriNya sendiri," (Ibr. 10:20). Yesus mengorbankan diri-Nya sendiri sebagai jalan supaya relasi antara manusia dengan Allah dapat diperbaiki.

Allah menciptakan manusia segambar dan serupa dengan Allah. Artinya adalah manusia mengekspresikan kasih Allah. Manusia mampu melakukan beberapa ekspresi kasih yang dilakukan Allah. Setelah manusia jatuh ke dalam dosa gambar diri itu menjadi rusak dan manusia lebih menyukai kejahatan. Banyak aspek dalam diri manusia yang berubah mulai, pola pikir, tingkah laku, sikap dipengaruhi secara negatif.

28 Junihot S, Psikologi Pendidikan Agama Kristen(Yogyakarta : Andi,2016) ,41. 
Manusia cenderung lebih mudah bertindak dan berpikir hal-hal yang negatif. Memandang diri sendiri secara negatif dan orang lain. Gambar diri manusia yang telah rusak sangat mempengaruhi konsep penilaian terhadap diri sendiri. Peneliti melihat kaitan antara konsep diri manusia yang jatuh dalam dosa dengan konsep diri korban tindakan percabulan. Seorang korban percabulan akan menganggap dirinya sebagai pribadi yang tidak berharga, kotor, rusak. Sangat mungkin dengan penilaian yang buruk terhadap diri sendiri sehingga sulit untuk mengasihi diri sendiri.

Perubahan negatif pada konsep diri korban dapat berakibat buruk pada dirinya sendiri. Seorang yang menganggap dirinya tidak berharga, kotor dan rusak dapat secara psikis akan mendorong dirinya untuk tidak mengasihi dirinya sendiri. Tindakan lain yang dapat muncul sebagai ekspresi tekanan psikologis adalah dengan menjadikan dirinya pelaku. Pelaku dalam artian seorang korban yang nyaman dengan dirinya setelah menjadi korban percabulan sehingga menganggap dirinya "sudah terlanjur menjadi orang yang kotor".

\section{Relasi Dalam Keluarga}

Keluarga menjadi organisasi terkecil yang terdiri dari anggota keluarga. Setiap individu di dalamnya memiliki fungsi dan perannya masing-masing sehingga tercipta suasana yang dinamis. Jika salah satu dari individu mengalami masalah maka akan mempengaruhi relasi dalam keluarga.

Terjadinya tindakan percabulan di dalam keluarga dapat dipengaruhi oleh berperan atau tidaknya anggota keluarga dengan baik. Anggota keluarga yang berperan dengan baik akan meminimalisir adanya masalah di dalam keluarganya. Jika salah satu dari anggota keluarga mengalami kasus yang serius dan mengakibatkan trauma, hal ini akan mempengaruhi relasinya dengan sesama anggota keluarga.

Kekurangan kasih pada masa kecil menyebabkan kebutuhan akan rasa amannya tidak terpenuhi. la tumbuh menjadi orang yang kaku dan cenderung mengembangkan motto hidup "aku harus hidup sendiri", "aku tidak butuh orang lain". Daripada memperhatikan nasihat orang lain, ia lebih mempercayai perasaan dan pikirannya sendiri yang tidak selalu benar. ${ }^{29}$

Kekurangan kasih sayang pada masa kecil akan mempengaruhi pemahaman anak dalam menjalin relasi di dalam keluarganya. Ketika anak menjadi korban percabulan tetapi ia memiliki latar belakang sebagai anak yang kekurangan kasih sayang dari orang tua akan membahayakan dirinya sendiri dan relasinya. Seorang anak akan leluasa berbagi cerita dan permasalahannya kepada orang yang ia percaya dan dekat dengan dia.

\footnotetext{
${ }^{29}$ Agnes Maria Layantara, ibid., 29.
} 
Anggota keluarga yang sehat akan memiliki ciri-ciri yang sehat dan dinamis. Sebaliknya keluarga yang "sakit" juga memiliki ciri-ciri tertentu dalam keluarganya. Keluarga yang sehat seharusnya mampu memiliki sikap saling menghargai, menjadi wadah menemukan dan mengembangkan bakat, menunjukkan kasih dan menghargai batas-batas dan menjaga disiplin. ${ }^{30}$

Relasi dalam keluarga dipengaruhi oleh hal-hal tersebut di atas, jika keluarga tidak memiliki ciri-ciri keluarga yang sehat dapat mempengaruhi relasi antar anggota keluarga. Dengan ciri-ciri ini jika seorang anak korban percabulan akan cenderung menyalahkan dan menganggap keluarganya tidak menjadi teladan dan model yang baik.

\section{Kondisi Psikologis}

Manusia diciptakan dengan rangkaian tubuh, jiwa dan roh yang bekerja secara luar biasa. Tubuh atau fisik manusia mengalami pertumbuhan dan perkembangan seiring berjalannya waktu dan usia. Sedangkan jiwa dan roh sifatnya adalah kasat mata, tidak dapat dilihat perubahan dan perkembangannya. Tubuh, jiwa dan roh manusia menjadi satu kesatuan yang saling berkaitan.

Keadaan psikologis berkaitan dengan psikologi atau keadaan kejiwaan seseorang. Kondisi kejiwaan manusia dipengaruhi oleh berbagai faktor yang dialami manusia tersebut. Berbagai pengalaman yang mengakibatkan trauma, pengalaman yang dramatis dan pengalaman yang menyakitkan akan mengakibatkan otak merekam pengalaman ini. Akibat dari pengalaman menyakitkan ini menimbulkan efek yang serius pada kejiwaan seseorang.

Memori pada otak manusia yang merekam peristiwa-peristiwa yang mengakibatkan luka yang mendalam. Peristiwa-peristiwa yang mengakibatkan shock pada manusia akan terekam di dalam otak dan tersimpan di dalamnya. Tidak akan mudah untuk hilang karena kejadian peristiwa itu mengakibatkan tekanan batin. Memori otak manusia menjadi sebuah misteri. Hebatnya sebuah memori karena ia merekam hal-hal tertentu bahkan sebelum manusia dilahirkan di dunia. Dr. Thomas Verny mengatakan. "How far back we can push the frontiers of memory? the time article states, "The search for data is being steadily pushed back from childood to earliest infancy and even before birth"31.

Kondisi psikologis yang umum dialami manusia adalah stress. Hal ini dialami bukan hanya oleh manusia yang "sakit" karena pengalaman-pengalaman yang menyakitkan saja tetapi juga dialami oleh manusia yang normal pada

\footnotetext{
30 Julis Ishak Abraham Memulihkan Taman Eden Dalam Keluarga(Yogyakarta:And,2007),52.

${ }^{31}$ David A. Seamands, HealingOf Memories(Illinois: Victor Books, 1985), 20.
} 
umumnya. Stress atau gangguan pada kejiwaan seseorang memiliki tingkat yang berbeda-beda. Tingkat stress tertentu tidak hanya berdampak pada kejiwaan tetapi fisik juga akan mengalami gangguan.

Orang yang mengalami stress akan timbul berbagai patofisiologis stress, yaitu gangguan yang akan terjadi pada pada organ tubuh apabila seseorang stress. Di antaranya, kelenjar anak ginjal membesar dan akan berwarna gelap. Selain itu zat telur dalam darah akan berangsur-angsur menurun dan yang sering terjadi, selaput lendir lembung akan mengalami luka dan berdarah. Itulah orang yang sering stress akan mengalami nyeri lambung. ${ }^{32}$

Pendapat di atas menjelaskan kaitan antara fisik dan psikis tidak dapat dipisahkan. Sesuatu yang ada di dalam pikiran manusia dan ada di dalam hati yang tidak diungkapkan, akan dinyatakan oleh gangguan-gangguan pada fisik yang dapat dilihat dan dirasakan oleh orang lain.

Tekanan psikis yang memiliki skala tertentu selain berdampak pada patofisiologis stress akan memicu seseorang melakukan tindakan tertentu. Tindakan inilah dinamakan emosi.

Semua emosi, pada dasarnya, adalah dorongan untuk bertindak, rencana seketika untuk mengatasi masalah yang telah ditanamkan secara berangsur-angsur oleh evolusi. Akar kata emosiadalah movere, kata kerja bahasa Latin yang berarti "menggerakkan, bergerak", ditambah awalan "e-" untuk memberi arti "bergerak menjauh", menyi-ratkan bahwa kecenderungan bertindak merupakan hal mutlak dalam emosi. ${ }^{33}$

Stres memicu emosi seseorang untuk melakukan tindakan sebagai cara untuk mengekspresikan dirinya. Setiap hari emosi mempengaruhi kinerja anggota tubuh. Hal ini juga disampaikan oleh Clyde M. Narramore.

Knowing how these normal, everyday emotions influence body functions, we are better able to understand how, over a period of time, strong and persistent emotional conflicts may disturb the working of body organs such as the heart or the stomach. It is believed that in some cases they can eventually result in an actual change in the organ itself. ${ }^{34}$

Clyde menyatakan hal yang normal berkaitan dengan emosi manusia. Emosi mempengaruhi fungsi tubuh dan organ-organ dalam tubuh akan mengalami gangguan. Emosi sebagai ekspresi dari stress manusia, sebagaimana emosi menyatakan keadaan kejiwaan manusia. Ekspresi emosi akan menyatakan kondisi kejiwaan manusia yang lebih akurat jika dibandingkan dengan mengutarakan melalui perkataan. Emosi yang diekspresikan melalui bahasa

\footnotetext{
${ }^{32}$ Hadi P. Sahardjo, Konseling Krisis Dan Terapi Singkat Pertolongan Di Saat-Saat Sulit(Bandung: Pionir Jaya, 2008), 81.

${ }^{33}$ Daniel Goleman, Emotional Intelligence(Jakarta: Gramedia Pustaka Utama,1996), 7.

${ }^{34}$ Clyde M. Narramore, The Psychology of Counseling(California: Grand Rapids,1960), 163.
} 
tubuh lebih jujur karena bahasa tubuh merupakan hasil stimulus respon, sedangkan kata-kata hasil proses mental, proses berpikir dan analisa seseorang.

\section{PENANGANAN TRAUMA TERHADAP PERCABULAN}

Penanganan trauma healing dibutuhkan beberapa komponen penting di dalamnya untuk mampu menolong korban. Komponen yang ada di dalam trauma healing adalah konselor, konsele dan metode yang digunakan untuk proses trauma healing. Komponen penting pertama adalah konselor, dalam bukunya Clyde M. Narramore mengatakan demikian :

what is the most important thing in counseling ?", The answer is, "The Counselor". Naturally, the counselor's techniques are very important. He should also have an understanding of human behaviour and knowledge of bibliography as well as sources of referral at his command. But the most important element in counseling is the counselor himself. ${ }^{35}$

\section{Sikap Konselor Kristen}

Seorang konselor harus seorang yang sudah dipulihkan dari trauma sehingga bisa menolong konsele menemukan solusi bagi problem yang ia hadapi. Konselor akan menggunakan pengalaman hidupnya, hidup yang sudah dipulihkan dan membawa konsele kepada prinsip Alkitab memandang suatu permasalahan. Gerry Colins menyatakan Sedangkan Konseling Kristen berorientasi pada Tuhan (theocentris), karena itu pengetahuan konseling bersumber dari Allah yang telah menyatakan Diri-Nya kepada manusia. "Oleh karena itu konselor Kristen percaya bahwa melalui Alkitab Allah telah memberikan prinsip-prinsip bagaimana seharusnya kita hidup." ${ }^{36}$

Penanganan trauma healing dapat berjalan efektif apabila konselor juga memiliki beberapa ciri-ciri yang menjadi sikap dan gaya hidup konselor kristen. Tulus Tu'u menuliskan dalam bukunya dasar-dasar konseling pastoral sebagai berikut:

- Percaya Kepada Yesus Sang Konselor Agung

Yesus Kristus, sang Konselor Agung adalah Tuhan, Juru Selamat, dan Pembebas. la datang ke dunia untuk membebaskan manusia dari rantai dan belenggu dosa (Yohanes 8:36). Inilah kemerdekaan sejati. Dosa yang merupakan akar segala persoalan telah diselesaikan oleh Konselor Agung.

\footnotetext{
${ }^{35}$ Clyde M. Narramore, The Psychology of Counseling.,Ibid164.

${ }^{36}$ Gary R. Collins, The Biblical Basis of Christian Counseling for People Helpers (Colorado: Navpress Publishing Group, 1993), 11-12.
} 
Konselor Kristen harus orang yang sungguh-sungguh percaya dan menerima Yesus Kristus sebagai Tuhan, Juru Selamat, dan Konselor Agung dalam hidupnya. Jika kita tidak mengenal Konselor Agung, mustahil kita dapat memimpin orang datang kepada-Nya.

Yesaya 9:6 sebab seorang anak telah lahir untuk kita, seorang putra telah diberikan untuk kita; lambang pemerintahan ada di atas bahunya, dan namanya disebutkan orang: Penasihat Ajaib, Allah yang perkasa, Bapa yang kekal, Raja damai. Kitab Yesaya bagian ini menjelaskan bahwa Yesus Kristus adalah sebagai The Best Counselor.

\section{- Telah Menerima Kristus Secara Pribadi}

Percaya harus dilanjutkan dengan respon menerima Yesus Kristus. Penerimaan ini bersifat sangat personal. Bukan karena terpaksa tetapi sukarela dengan kesadaran diri. Kristus sudah berdiri di depan pintu hati kita. Apakah kita akan mempersilakan Dia masuk ke dalam hati dan hidup kita? Ataukah kita masih membiarkan Dia tetap tinggal di luar?

Seharusnya, kita mempersilakan dan mengundang Kristus masuk ke dalam hati dan hidup kita. Artinya, menerima Dia untuk pertama kali, (Wahyu 3:20). Jadi, respon percaya, mengikuti, dan menerima Kristus Tuhan bersifat sangat pribadi. Harus dilakukan dengan kerelaan dan kesadaran diri. Pengalaman bersama Kristus juga bersifat pribadi. Meskipun orang tua kita Kristen, tidak otomatis kita menjadi Kristen. Tanpa hidup bersama Kristus, yang ada hanya sekadar beragama saja. Oleh sebab itu, kita perlu mengundang Kristus masuk dan mempersilakan Dia menguasai hidup kita sepenuhnya.

- Menerima Otoritas Alkitab Sebagai Pedoman Hidup

Hidup, perilaku, perbuatan, dan sikap manusia dipengaruhi oleh berbagai hal, antara lain: adat, budaya, pendidikan, pengetahuan, masa lalu, pengalaman, pandangan keyakinan, kepribadian (sikap dan sifat), lingkungan dan status sosial dalam masyarakat. Hal-hal itu banyak memengaruhi pola perilaku seseorang dalam hidup sehari-hari.

Seorang konselor, Alkitab sangat penting dan seharusnya memengaruhi perilaku moral dan etika hidupnya. Dia harus menerima dan mengakui otoritas Alkitab sebagai pedoman perilaku moralnya. la bersedia untuk taat dan setia pada firman-Nya. Bahkan, ia perlu membagikan keyakinannya kepada konseli. 
Alkitab adalah firman Allah yang dianugerahkan kepada manusia. Firman itu berfungsi sebagai makanan rohani penyegar jiwa, pelita hidup, penuntun di jalan yang benar, pembimbing pada keselamatan, pemberi hikmat kepada orang yang tidak berpengalaman, penunjuk kesalahan, dan pendidik dalam kebenaran (Mazmur 19:8, 119:105, Yesaya 45:19, Matius 4:4, 2 Timotius 3:15-17).

\section{- Menghayati Tugas dan Panggilan}

Konseling pastoral tidak bisa dilakukan secara amatiran sebab jika demikian, kita akan melayani tanpa hati dan motivasi yang benar. Sebaliknya, kita seharusnya bekerja karena panggilan yang dilakukan secara profesional. Artinya, konselor merasakan dan meyakini bahwa ia dipanggil oleh Konselor Agung untuk melayani domba-domba-Nya. Ketika melayani konseli, ia sudah melayani Tuhan, Konselor Agungnya (Kolose 3:17,23).

Agar panggilan pelayanan itu baik di mata Tuhan dan manusia, konselor perlu bertindak profesional. Karya dan jerih lelah itu pasti akan diberkati. Tidak ada yang mustahil bagi Tuhan. la Mahakuasa dan dapat menggerakkan orang-orang untuk menjadi saluran berkat bagi konselor. Tuhan tidak membiarkan dia sendiri (2 Timotius 1:12).

\section{Langkah-langkah Penanganan}

Penanganan Trauma Healing ini menggunakan Biblical Counseling. Wayne A. Mack dalam buku Introduction to Biblical Counseling mengatakan demikian: Biblical counseling is about solving people's problems. It's about discovering the causes of their problems and then applying biblical principles to those causes. Sometimes, even well intentioned counselors err, however, by counseling without cultivating the key element of involvement. ${ }^{37}$

Ayat suci Alkitab memuat berbagai problem manusia. "Alkitab berbicara dengan otoritas mengenai pikiran, perasaan, dan masalah-masalah patologis/penyakit seperti gangguan kekuatiran, depresi, kemarahan dan kepahitan. Lagipula, sejak kita diubah oleh pembaruan budi kita (Roma 12:2), kita harus, jika ingin menjadi serupa dengan gambaran-Nya, memahami pikiran berfungsi. Dan kesadaran semacam ini juga merupakan bagian penting dalam proses penyucian. ${ }^{38}$

Itulah sebabnya mengapa segala problem manusia harus dikembalikan kepada bagaimana Alkitab memandang permasalahan tersebut. Pribadi Yesus

\footnotetext{
${ }^{37}$ John F. MacArthur, JR. dan Wayne A. Mack, Introduction to Biblical Counseling(United States of America: Word Publishing, 1994),173.

${ }^{38}$ Neil T. Anderson dan Terry E. Zuehlke, Christ Centered Therapy (Malang: Gandum Mas,2014), 11.
} 
Kristus yang adalah The best counselor telah dituliskan di dalam Alkitab, cara la menangani dan menolong manusia menemukan solusi permasalahannya. Seorang konselor kristen jauh lebih berhasil dalam menolong konsele daripada yang lain. Clyde M. Narramore mengatakan demikian:

Undoubtedly some Christian counselors are more succesful than others because they are more skilled in the use of Scripture. The following suggestion will aid the counselor in presenting the precious Word of God. ${ }^{39}$

Penanganan konseling terhadap korban kasus abuse atau percabulan penting untuk mengidentifikasi beberapa hal yang berkaitan dengan psikologis seseorang. Neil T. Anderson mengatakan demikian "karena manusia adalah mahluk yang kompleks, penting bagi anggota-anggota profesional lainnya yang membantu untuk memahami tidak saja bagaimana otak berfungsi (neurologi) tetapi juga bagaimana pikiran bekerja (psikologi). ${ }^{40}$

Beberapa tahapan dalam penanganan trauma healingmenggunakan Biblical Counseling antara lain sebagai berikut :

- Mengidentifikasi Masalah Perasaan

Kebanyakan orang memulai konseling dengan mendiskusikan mengenai perasaan mereka. Tujuan awal konselor adalah untuk menunjukkan dengan tepat apapun masalah emosi yang ada. Jika klien memulai dengan berbagi perasaan, merenungkan, menarik, memahami, mengklarifikasi. Maka cobalah untuk mengidentifikasi apakah perasaan itu kecemasan, kebencian, keputusasaan, rasa bersalah atau perasaan hampa yang samar. Jika klien memulai dengan membahas keadaannya, tanyakan bagaimana perasaannya terhadap keadaannya. Sekali lagi tujuannya adalah untuk mengidentifikasi masalah perasaan mana yang tampaknya menjadi masalah utama. Rogers menyatakan bahwa "perasaan adalah fokus awal untuk membantu konselor melacak kembali ke akar masalahnya." 41

- Mengidentifikasi Tujuan yang Berorientasi Pada Masalah Perilaku Tahap kedua dalam penanganan metode Biblical Counseling adalah mengidentifikasi tindakan yang dilakukan ketika klien mengalami hambatan yang menciptakan perasaan negatif. Hal ini jauh lebih baik daripada mengatakan "mengapa kamu merasa seperti itu?". Seluruh analisis dimulai dengan mengidentifikasi masalah perasaan, misalnya (kebencian) kemudian mengidentifikasi perilaku (masalah) yang berorientasi pada tujuan.

\footnotetext{
${ }^{39}$ Clyde M. Narramore., Ibid255.

${ }^{40}$ Neil T. Anderson dan Terry E. Zuehlke., Ibid11.

${ }^{41}$ Lawrence J. Crabb, Effective Biblical Counseling(Michigan: Grand Rapids, 1977), 149.
} 
Dalam bagian ini klien juga diminta untuk mengutarakan ingatan awalnya. Ingatan yang awal akan memberikan petunjuk mengenai perilakunya. Ingatan awal yang dimaksudkan adalah akar dari suatu peristiwa yang membuat klien memiliki persepsi dan tindakan yang memblokir perilakunya yang berorientasi pada tujuan.

- Mengidentifikasi Masalah Pikiran

Langkah selanjutnya adalah meyakinkan klien bahwa pemikirannya salah. Karena asumsi diyakini secara emosi, konseling yang mendalam membutuhkan jauh lebih dari sekedar mengidentifikasi asumsi yang salah dan menyatakan altematif Alkitabiah. "seorang psikolog dapat menggunakan prinsip-prinsip yang efektif saat menghadapi emosi dan perilaku manusia sepanjang prinsip-prinsip tersebut sesuai dengan Alkitab. Kuncinya adalah melihat psikologi dengan kacamata Alkitab." ${ }^{42}$ Beberapa saran yang relevan untuk mengubah pemikiran yang salah menjadi pemikiran yang benar.Lawrence J. Crabb menyatakan:

a. Identifikasi dimana asumsi yang salah dipelajari. Ketika seorang klien melihat bahwa serangkaian keadaan tertentu mengajarinya tentang keyakinannya saat ini. Klien dapat melihat bahwa sumbernya mungkin tidak salah. Berbicara mengenai kebenaran keyakinannya mungkin lebih mudah jika konselor dapat menunjukkan di mana dia mempelajarinya.

b. Mendorong ekspresi emosi yang terkandung di sekitar kepercayaannya. Konselor harus mendengarkan perasaan apapun yang terkait dengan asumsi yang disampaikan oleh klien. Konselor yang peka akan merefleksikan emosi apapun yang diterimanya ketika asumsi dasar klien dibahas. Ketika klien merasa dipahami ia akan merasa santai.

c. Dukung klien ketika dia mempertimbangkan untuk mengubah asumsiasumsinya. Meninggalkan asumsi yang sudah lama dipegangnya sendiri merupakan proses yang mengancam kenyamanan. Perlawanan pada poinnya seringkali adalah ketakutan untuk meninggalkan kenyamanan. Konselor perlu menawarkan dorongan dan dukungan.

d. Ajari klien tentang apa yang harus mengisi pikirannya. Crabb sering menyarankan kepada klien untuk menganggap pikiran mereka sebagai alat perekam. "Kemudian meminta kepada mereka menuliskan pada kartu mereka tentang anggapan yang salah dan meminta mereka menuliskan di kartu yang lain mengenai asumsi yang bertentangan dengan Alkitab. Setiap kali mereka merasa kesal (bersalah, kesal atau cemas) Crabb menginstruksikan mereka untuk membaca kedua kartu dan memutar ulang

42 Lawrence J. Crabb. Ibid77. 
kalimat dengan contoh Alkitab. Setelah klien secara tentatif menangkap pemikiran baru dan setidaknya dapat mengenali kesalahan dari asumsi lamanya maka empat tahap ini selesai."

- Komitmen yang Kokoh

Tahap selanjutnya melibatkan pengokohan komitmen untuk melakukan tindakan yang baru saja dipelajari. Klien harus bertindak konsisten dengan kontennya karena, perubahan perilaku tidak akan mengalir secara otomatis jika hanya dipikirkan tetapi membutuhkan komitmen yang teguh.

Konseling tidak dapat berkembang melewati bagian ini sampai klien telah benar-benar berkomitmen pada dirinya sendiri, berperilaku secara konsisten dengan apa yang ia akui benar terlepas dari bagaimana perasaannya. Pada tahap inilah pengakuan dosa tampaknya tepat untuk dinyatakan. Tidak hanya perilaku yang salah (memanipulasi pasangan, dosa seksual) harus diakui.

- Menyampaikan Peran Spiritual

Tahap akhir adalah mengidentifikasi perasaan berdosa dan kehadiran hal spiritual. Perkembangan rasa tenang, kebersamaan, dan kedamaian adalah pengalaman yang memuaskan dan menentramkan hati. Konselor hendaknya mencari bukti mengenai kehadiran Roh dalam kehidupan klien dan memastikan bahwa hal itu dirasakan oleh klien.

Penanganan kasus ini melibatkan antara psikologi dan spiritual. Tentu sebelum memasukkan unsur dan aspek spiritual harus menganalisa aspek psikologis terlebih dahulu. Neil T. Anderson dan Robert Saucy mengatakan bahwa tetap ada psikologi yang alkitabiah. Artinya pelayanan dengan metode Biblical Counseling itu tetap ada.

Alkitab berbicara dengan otoritas mengenai pikiran, perasaan, dan masalah-masalah patologis atau penyakit seperti gangguan kekuatiran, depresi, kemarahan dan kepahitan. Lagipula, sejak kita diubah oleh pembaharuan budi kita (Roma 12:2), kita harus jika ingin menjadi serupa dengan gambaran-Nya. Memahami bagaimana pikiran berfungsi dan kesadaran semacam ini juga merupakan bagian penting dalam proses penyucian. ${ }^{43}$

Konseling kristen memiliki bagian yang penting mengenai identitas manusia yang baru dalam Kristus. Bagian penting dalam sesi konseling adalah menyampaikan identitas dan nilai manusia di hadapan Allah. Teolog Inggris, John Stott menuliskan

Jadi, dalam prakteknya kita harus terus mengingatkan diri kita sendiri siapa kita. Kita perlu belajar berbicara dengan diri kita sendiri, dan

${ }^{43}$ Neil T. Anderson dan Robert Saucy, The Common Made Holy (Eugene: Harvest House, 1997), 12. 
menanyai diri kita sendiri pertanyaan-pertanyaan: 'tidakkah kamu tahu? Tidakkah kamu tahu makna pertobatan dan baptisan? Tidakkah kamu tahu bahwa kamu sudah dipersatukan dengan Kristus di dalam kematian dan kebangkitanNya? Tidakkah kamu tahu bahwa kamu telah menjadi hamba Allah dan mengabdikan dirimu dalam ketaatan kepada-Nya ? Tidakkah kamu tahu hal-hal ini? Tidakkah kamu tahu siapa kamu?' kita harus terus mendorong dir kita menanyai pertanyaanpertanyaan seperti ini, sampai kita menjawabnya untuk kita sendiri: "Ya, aku tahu siapa aku, pribadi yang baru dalam Kristus, dan dengan kasih karunia Allah maka aku akan hidup. ${ }^{44}$

Peran spiritual dalam konseling Kristen sebagai meterai yang mengokohkan. Manusia dalam segala kondisi yang dikatakan tidak layak, rusak dan tidak berharga akan didorong untuk melihat nilai mereka di hadapan Tuhan adalah tetap sama. Manusia sama nilainya di hadapan Allah dan tetap berharga, untuk itulah Yesus Kristus mengorbankan diri-Nya untuk semua orang.

Ayat-ayat suci Alkitab yang dapat digunakan dalam pelayanan trauma healing adalah menekankan kembali gambar diri yang baru di dalam Kristus. Di dalam Dia semua orang memiliki identitas yang baru. Diterima dalam Kristus (Aku adalah sahabat Allah, Yoh.15:15; Aku telah dibayar dan harganya telah lunas dibayar, aku milik Allah. 1 Kor.6:20; Aku adalah anggota tubuh Kristus, 1 Kor.12:27; Aku sudah ditebus dan diampuni dari segala dosa-dosaku, Kol.1:14). Aman di dalam Kristus (Aku bebas selamalamanya dari penghukuman, Rm.8:1-2; Aku tidak dapat dipisahkan dari kasih Allah, Rm.8:35; Aku tersembunyi bersama dengan Kristus di dalam Allah, Kol.3:3; Aku dapat menemukan kasih karunia dan belas kasihan di saat membutuhkan, Ibr.4:16). Penting di dalam Kristus (Aku adalah garam dan terang dunia, Mat. 5:13-14).

\section{KESIMPULAN}

Pelayanan trauma healing bagi korban tindakan percabulan sangat dibutuhkan. Pada semua sesi konseling selalu diawali dengan anamnesa atau menggali informasi dan mengidentifikasi masalah perasaan, mengidentifikasi masalah pikiran, dan menyampaikan peran spiritual. Dalam penanganan kasus percabulan proses pendampingan harus melibatkan empat aspek yaitu fisik, sosial, mental dan spiritual.

Aspek fisik berhubungan dengan pertolongan pada tahap pertama jika terdapat luka secara fisik akibat tindakan percabulan. Aspek sosial merupakan pemulihan dengan jalur hukum yaitu memberlakukan tindakan pidana

\footnotetext{
${ }^{44}$ John Stott, Romans: God's Good News for the World (Downers Grove, III: InterVarsity Press, 1994), 187.
} 
bagi pelaku kejahatan yang di proses secara hukum. Aspek mental dan spiritual disampaikan untuk menyampaikan bahwa nilai manusia di hadapan Tuhan tetap sama yaitu berharga di mata Tuhan.

Sikap dan tindakan konselor kristen dalam memberikan pelayanan trauma healing harus memperhatikan kualifikasinya. Konselor haruslah orang yang sudah dipulihkan dari trauma. Sehingga konselor dapat menolong orang lain untuk pulih. Konselor setidaknya memiliki pengetahuan mengenai psikologis manusia karena dalam penanganan dan pendampingan penting bagi anggota-anggota profesional lainnya yang membantu untuk memahami tidak saja bagaimana otak berfungsi (neurologi) tetapi juga bagaimana pikiran bekerja (psikologi). Tetapi yang lebih penting dari itu adalah tetrampil menggunakan aspek teologis dalam pendampingan. Aspek teologis akan melibatkan peran spiritual yaitu Roh Kudus dalam pendampingan bekerja melampaui akal pikiran manusia.

Pada pelayanan trauma healing korban percabulan terdapat kendala yaitu pada klien sendiri, keluarga, sosial masyarakat. Pendampingan menjadi terkendala jika klien tidak ingin ditolong, dari keluarga akan menghambat proses pemulihan dan pendampingan jika keluarga tidak memberikan dukungan. Dari sosial masyarakat pendampingan akan menjadi terhambat jika pelaku tidak ditindak lanjuti secara hukum oleh pihak yang berwenang.

\section{DAFTAR PUSTAKA}

Webster, Noah. 1979. Webster's New Universal Unabridged Dictionary, New York: World Publishing Co.

Martam, Irma S. Mengenali Trauma Pasca Bencana, Pulih, 14 Desember 2009, 2. http://www.pulih.or.id/res/publikasi/news_letter_14.pdf

Mifflin, Houghton. 1984. Webster's II New Riverside University Dictionary Boston Company, Massachusetts.

Meyer, Joyce. 1994. Perhiasan Kepala Ganti Abu Bebas Dari Kenangan Menyakitkan, Jakarta:Metanoia.

Esfand, Muthia. 2012. Women Self Defense, Jakarta: Visi Media.

Hunt, June. 2015. Pastoral Konseling Alkitabiah Menjawab Isu-Isu Etika Sekuler Masa Kini 2, Yogyakarta: ANDI.

Anderson, Neil. T. 2004. Jalan Pelepasan Kebebasan dari Belenggu Seksual. Ungaran: Kanugrahan. 
Linden, Nico Ter. 2009. Cerita Itu Berlanjut Cara Baru Membaca HakimHakim dan Raja-Raja, Jakarta: BPK Gunung Mulia.

Hakh, Samuel Benyamin. 2010. Perjanjian Baru Sejarah, Pengantar dan Pokok-pokok Teologisnya. Bandung: Bina Media Informasi.

https://hellosehat.com/hidup-sehat/psikologi/dampak-bullying-pada kesehatan-mental-dan-fisik-anak/ Rabu, 16 Januari 2019 Pukul 04.39

Junihot S, 2016. Psikologi Pendidikan Agama Kristen. Yogyakarta: Andi.

Abraham, Julis Ishak. 2007. Memulihkan Taman Eden Dalam Keluarga. Yogyakarta: Andi Offset.

Seamands, David A. 1985. Healing of Memories, Illinois: Victor Books.

Sahardjo, Hadi P. 2008. Konseling Krisis Dan Terapi Singkat Pertolongan Di Saat-Saat Sulit, Bandung: Pionir Jaya.

Goleman, Daniel. 1996. Emotional Intelligence. Jakarta: Gramedia Pustaka Utama.

Narramore, Clyde M. 1960. The Psychology of Counseling. California: Grand Rapids.

Collins, Gary R. 1993 The Biblical Basis of Christian Counseling for People Helpers Colorado: Navpress Publishing Group,

MacArthur, John F. Jr. dan Mack, Wayne A. 1994. Introduction to Biblical Counseling. United States of America: Word Publishing.

Anderson, Neil T. dan Zuehlke,Terry E. 2014. Christ Centered Therapy, Malang: Gandum Mas.

Crabb, Lawrence J. 1977. Effective Biblical Counseling. Michigan: Grand Rapids.

Stott, John. Romans: 1994. God's Good News for the World. Downers Grove, III: InterVarsity Press. 